\title{
Applying Total Quality Management Cost Model in Drug Intervention Programme
}

\author{
Sharifah Fadzlon Abdul Hamid, Normah Omar, Suzana Sulaiman, Wee Shu Hui, and Rusli Ismail
}

\begin{abstract}
Total Quality Management has been applied widely in the business sector in particular to assess the impact of continuous quality in the day to day operation. The emphasis was more on preventive than cure. Many government sectors in Malaysia are moving towards adopting this concept to ensure that quality product and services are delivered to their customers. In this paper, the researcher introduces the concept of TQM to cost drug intervention programme in particular the Needle and Syringe Exchange Programme (NSEP), conducted in Kota Bharu, Kelantan, Malaysia. The paper also measures the effectiveness of the activities using the concept of $4 \mathrm{Cs}$. The framework has never been used before to cost and at the same time determine the effectiveness of harm reduction programme. The result demonstrated that the NSEP is cost effective in preventing the spreading of HIV virus through needle-syringe sharing. It also reveals the importance of creating awareness among the public about the programme and the benefits of such programme. The research findings will better promote the programme to the government so that a larger investment would be made to prevent the spreading of HIV virus in the country.
\end{abstract}

Index terms-4Cs, harm reduction, NSEP, total quality management.

\section{INTRODUCTION}

In the past, cost effectiveness on the harm reduction programmes were conducted through the eyes of non-management accountant. These work mostly involved classifying and quantifying the costs of harm reduction, as evident by some literatures. Any costs that relates to detecting and treating of diseases were classified as direct costs whereas costs that relates to any production lost as a result of premature mortality, morbidity and the use of health care services were classified as indirect costs [1].The intervention costs have also been classified as financial costs and economic costs [2]. In measuring the effectiveness of the activities, productivity costs were also introduced which described some indirect costs associated to intervention activities [3]. The harm reduction has also been identified as annual costs of methadone substitution; additional counselling and program support costs as well as annual health costs [4].In this paper the authors will costs the activities relating to harm reduction using the total quality management by introducing the $4 \mathrm{Cs}$.

Manuscript received September 5, 2013; revised November 8, 2013.

Sharifah Fadzlon Abdul Hamid, Normah Omar, Suzana Sulaiman, and Wee Shu Hui are with the Accounting Research Institute and Faculty of Accountancy, Universiti Teknologi MARA, Malaysia. (e-mail: shari355@salam.uitm.edu.my, normah645@salam.uitm.edu.my)

Rusli Ismail is with the University Malaya, Malaysia.

\section{TOTAL QUALITY MANAGEMENT (TQM)}

One of the main principles underlying the TQM is prevention whereby emphasising on prevention will eventually leads to less activities and costs on curing. In the long run, it is cheaper to stop products defects than trying to repair. The concept is very similar to the harm reduction activities conducted by many countries whereby the government of each country is the main provider of funds.TQM has already been applied in the Public Health services and later incorporated in the Agenda for Change by the Joint Commission of the Accreditation of Healthcare Organisation [5].

\section{4Cs}

The 4Cs concept is developed based on ideas adapted from the TQM model. A preliminary round of interviews with medical staff involved with various harm reduction programmes and visits to harm reduction programmes provided the basis for the development of the $4 \mathrm{Cs}$ model.

\section{HARM REDUCTION}

Harm reduction refers to activities to prevent the spreading of HIV/AIDs among the drug users and their family members [6]. The introduction of harm reduction, particularly needle exchange, was met with much public opposition [7]-[10]. However, transmission of HIV is found largely due to sharing of syringes among drug users and practicing unsafe sex. The activities involved promotion of safe drug use practices and sexual behavior through provision of condoms, syringes and information materials [11]. Apart from preventing the spread of HIV, harm reduction strategies also aim to raise awareness and provide education within the IDU community about HIV and other diseases [12].

\section{SAHABAT}

SAHABAT is a non-governmental organization that introduced the NSEP working for and with drug use community in Kelantan. The mission of SAHABAT is to help the IDUs that are HIV positive/AIDs to live a life without stigma and discrimination. The vision is to ensure that Malaysia is free from stigmatization and discrimination towards the HIV/AIDs and promote harm reduction.

SAHABAT activities include the dissemination of information about harm reduction, NSEP, MMT and medical references. 


\section{Methodology}

The data related to the costs was provided by SAHABAT in the form of annual financial statement. The information is required to determine the financial costs of running the harm reduction activities. The financial statement gives detail of the income which is the provision given by Malaysian Aids Council and the disbursement through the incurrence of the expenses. Generally, the costs are sub divided into project specific costs and administration costs. The costs were later reclassified according to the following framework (Table I) to differentiate between the costs of harm reduction also known as preventive costs and failure of harm reduction costs also known as consequences costs.

Interviews with the medical officers and the supervisor at SAHABAT were conducted to gain better insights of other notional costs that were not revealed in the financial statement.

TABLE I: COSTS FRAMEWORK FOR SAHABAT

\begin{tabular}{|c|c|c|c|c|}
\hline & \multicolumn{2}{|c|}{ Harm Reduction } & \multicolumn{2}{|c|}{$\begin{array}{l}\text { Failure of Harm Reduction Costs } \\
\text { (incurred as a result of the affected disease) }\end{array}$} \\
\hline TQM 4Cs & Awareness & Continuous Assessment & Internal Consequences & External Consequences \\
\hline Explaination & \begin{tabular}{ll}
\multicolumn{1}{c}{ Actual } & costs of \\
creating & awareness, \\
advertising, & education, \\
etc &
\end{tabular} & $\begin{array}{l}\text { Examining, locating and } \\
\text { monitoring cost on patients over a } \\
\text { period of time. }\end{array}$ & $\begin{array}{l}\text { The actual cost outlay on } \\
\text { treatment, alternative drugs, } \\
\text { rehabilitation, imprisonment, etc }\end{array}$ & $\begin{array}{l}\text { The extra cost of effected carers } \\
\text { on others. This includes influence } \\
\text { on the family members, follow-up } \\
\text { crimes, injuries to third parties and } \\
\text { society. }\end{array}$ \\
\hline
\end{tabular}

TABLE II: THE 4CS OF HARM REDUCTION

\begin{tabular}{|l|l|l|l|}
\hline Details & $\begin{array}{l}\text { Setup, communcations, salary of } \\
\text { outreach workers, initial training, } \\
\text { transportation for outreach work, } \\
\text { kit, needles and syringes, } \\
\text { condoms }\end{array}$ & $\begin{array}{l}\text { Salary, EPF, Socso, Insurance, } \\
\text { Medical costs for staff, } \\
\text { documentations, comunications, } \\
\text { rental transportation, upkeeping, } \\
\text { wear and tear, training costs }\end{array}$ & Loss on earnings \\
\hline 2009 & RM349,906.14 & RM95,694.33 & RM28,800 \\
\hline 2010 & RM338,324.29 & RM144,858.20 & RM72,000 \\
\hline 2011 & RM343,169.92 & RM135,442.46 RM414,000 & RM75,600 \\
\hline 2012 & RM256,612.90 & RM89,342.84 & RM408,000 \\
\hline JUNE 2013 & RM108,532.09 & RM23,462.65 & RM162,000 \\
\hline
\end{tabular}

\section{FINDINGS/DISCUSSIONS}

The costs shown (Table II) below are made up of the actual costs incurred by SAHABAT in conducting the outreach activities as well as other hidden or notional costs. These other costs are mainly economic costs that are borne by the government and public at large.

Awareness costs were made up of all the relevant costs for the outreach activities. Most of the costs vary with the number of contacts made and the number of outreach workers. The more the contacts made the more distribution of needles, syringes and condoms will be distributed. Thus, costs increased. Likewise, the larger number of workers will contribute to the increased in awareness costs.

However, most continuous assessment costs were administrative costs and therefore did not fluctuate with the number of clients. For all the years the costs of continuous assessment did not exceed RM150,000. And recently, the office for NSEP has shifted to a cheaper but more conducive premise.

According to the principle of TQM, the cost of awareness should be higher than the continuous assessment to reflect the effectiveness of the effort of reducing the spreading of HIV/AIDs. Higher investment in awareness indicates high commitment to prevent spreading of the virus so that less will be spent on curing. Costs of curing using HAART can be very expensive.

Internal consequences costs in this study were confined to the costs of treating the HIV/AIDs patients. Like other countries, Malaysia also used HAART for its patients and this is costing the government around $\$ 300$ to $\$ 400$ per month/patient.

The external consequences costs refer in this case to the costs of salary loss by the clients due to addictions and rehabilitations. Drug addicts often will lose jobs once their bad habits are known to their employers. However, 20\% of the registered clients have jobs. These are either fulltime or par-time jobs. Those that were referred for rehabilitation sessions will also lose their jobs. But upon release, $60 \%$ were able to gain jobs. This information was shared with the authors by the supervisor of the NGO.

The internal and external consequences costs vary with number of clients and for the five years are lower than the preventive costs. This would be in line with the concept of TQM where the overall costs of prevention should be lower than the consequences costs.

At the initial stage, the costs of creating awareness among the IDUs in particular and public in general were high (Fig. 1).The government alongside with the NGOs worked hard in persuading the drug users to participate in the NSEP. Outreaching activities were conducted by the SAHABAT staff at 4 outreach points and 23 meeting points.

Outreach is conducted 4 days a week and for every visit there will be two staffs involved. Every outreach day, two locations will be visited and for each visit the staff will spend around one hour with their clients and not more. This is because they do not want to be caught distributing the 
syringes by the police who will normally make their rounds near the IDUs meeting points. The fear to accidentally meet with the police is one of the contributing factors that during some days the number of clients that appear at the meeting points to exchange their needles and syringes are small. However, on average the outreach workers will meet about 30 clients per day visit.

After its first year, the program managed to successfully attract more clients. The clients were willing to undergo further health screening and seek medical assistance as well as rehabilitation. This caused many of the clients to lose their jobs. This is evidence by the increase in external consequences costs for the years 2010 and 2011. However, after four years in operation, the total costs of the programme have reduced. By now, the outreach workers need not travel to find new meeting points, Travelling costs are lesser. The clients are more willing to meet the outreach workers not only at the meeting points, but they can drop in at the SAHABAT office for fresh supplies of needles and syringes.

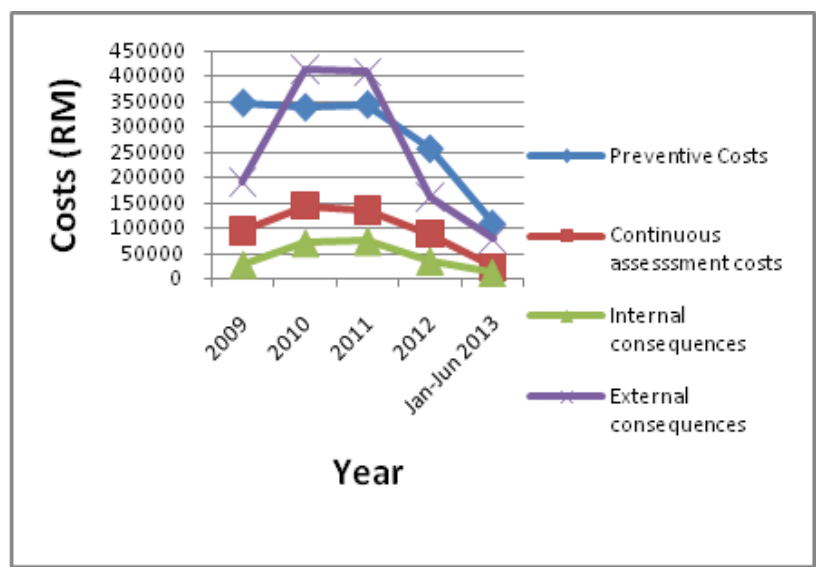

Fig. 1. The 4 Cs for the four and half years at SAHABAT.

Due to tight budgets, it was reported that in 2013, there was a budget cut on the programme. This contributed to the further reduction of the total costs. However, this did not deter the outreach workers to continue with their tasks. With a smaller number of staff, they managed to get new clients as shown in Table III, below.

TABLE III: NUMBER CLIENTS EACH YEAR REGISTERED AND OUTREACH WORKERS

\begin{tabular}{lllllll}
\multicolumn{1}{r}{ Year } & 2008 & 2009 & 2010 & 2011 & 2012 & $\begin{array}{l}\text { Jan-July2 } \\
013\end{array}$ \\
Clients & 2690 & 780 & 437 & 568 & 480 & 356 \\
$\begin{array}{l}\text { Total } \\
\text { clients }\end{array}$ & 2690 & 6868 & 5976 & 6643 & 6389 & 3418 \\
$\begin{array}{l}\text { Outreach } \\
\text { workers }\end{array}$ & 6 & 8 & 8 & 8 & 5 & 5
\end{tabular}

Even with a budget cut, the outreach workers managed to make contact with 356 clients mid 2013. Assuming the scenario remains, by the end of the year there will be more than 600 clients which is more than the last two years. This indicates that more drug addicts are aware of the importance of using clean needles and safe sex to prevent the spreading of HIV /AIDs. Their willingness to participate in the programme is also a sign that they are more responsible. The NSEP has indeed meets its objective.
The following (Table IV) will further explain that the NSEP is effective and should be continued. The cost per contact has reduced since it was first introduced.

TABLE IV: COST PER CONTACT FOR EACH YEAR

\begin{tabular}{|c|c|c|c|c|c|}
\hline Year & 2009 & 2010 & 2011 & 2012 & $\begin{array}{l}\text { Jan-Jul } \\
\text { y } 2013\end{array}$ \\
\hline $\begin{array}{l}\text { Preventive } \\
\text { costs per } \\
\text { contact }\end{array}$ & $\begin{array}{r}\text { RM } \\
27.59\end{array}$ & $\begin{array}{r}\text { RM } \\
35.22\end{array}$ & $\begin{array}{c}\text { RM } \\
26.22\end{array}$ & $24.53^{\text {RM }}$ & $\begin{array}{r}\text { RM } \\
19.68\end{array}$ \\
\hline $\begin{array}{l}\text { Consequenc } \\
\text { es costs per } \\
\text { contact }\end{array}$ & $\begin{array}{r}\mathrm{RM} \\
13.67\end{array}$ & $\begin{array}{r}\text { RM } \\
35.42\end{array}$ & $\begin{array}{r}\mathrm{RM} \\
26.50\end{array}$ & $\begin{array}{r}\text { RM } \\
17.82\end{array}$ & $\begin{array}{r}\mathrm{RM} \\
15.24\end{array}$ \\
\hline
\end{tabular}

The Malaysian Aids Council had recently reported that heterosexual habits are the major contributor for the spreading of HIV virus and not needles sharing indicating that the harm reduction programme initiated by the Government is successful (Fig. 2)

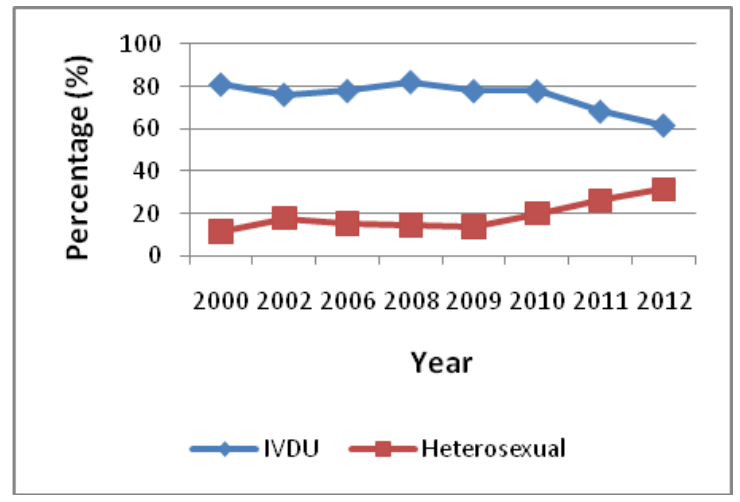

Fig. 2. New HIV cases according to the risk factors for 2000-2012

\section{CONCLUSION}

The intervention programme should be continued and more funding should come from the Malaysian Aids Council that received funds from the WHO. More organisations should take part in combating the spreading of HIV/ AIDs that may threat the economic stability of the country. The participation in the intervention may not only confine to the NSEP but rather to the root of the problem which is the supplies of the drugs to the users. Enforcement of laws and regulations are very crucial.

\section{ACKNOWLEDGEMENT}

Special thanks to Exploratory Research Grant Scheme (ERGS), Universiti Teknologi MARA (UiTM) for funding this research and SAHABAT Kota Bharu Kelantan for providing data. We also greatly appreciate INFORMM as research collaborator, Nor Hazeera Mohd Zan and Nur Shahida Ab Fatah,

\section{REFERENCES}

[1] A. Shiell and M. G. Law, "The cost of hepatitis C and the cost-effectiveness of its prevention," Health Policy, vol. 58, no. 2, pp. 121-131, 2001.

[2] P. Vickerman et al., "The cost-effectiveness of expanding ham reduction activities for injecting drug users in Odessa, Ukraine,' Sexually Transmitted Diseases, vol. 33, no. 10, pp. 89-102, 2006.

[3] P. Sendi, F. Schellenberg, C. Ungsedhapand, G. Kaufman, H. Bucher, R. Weber, and M. Battegay, "Swiss HIV Cohort Study, productivity 
costs and determinants of productivity in HIV-infected patients," Clinical Therapeutics, vol. 26, no. 5, pp. 791-800, 2004.

[4] S. S. Alistar, D. K. Owens, and M. L. Brandeau, "Effectiveness and cost-effectiveness of expanding harm reduction and antiretroviral therapy in a mixed HIV epidemic: a modelling analysis for Ukraine," Plos Med, vol. 8, no. 3.

[5] A. D. Kaluzny, C. P. McLaughlin, and K. Simpson, Public Health Report, vol. 107, no. 3, pp. 257-264, 1992.

[6] What is Harm Reduction? International Harm Reduction Association.

[7] A. Kamarulzaman, "Impact of HIV prevention programs on drug Users in Malaysia," Acquired Immune Deficiency Syndrome, vol. 52, supplement 1, pp. 17-19, 2009.

[8] N. Sarnon et al., "Psychosocial reactions of injecting drug users (IDU) towards needle and syringe exchange program in Malaysia," World Sciences Journal, vol. 12, pp. 80-84, 2005.

[9] M. Hasnain, "Cultural approach to HIV/AIDS harm reduction in muslim countries," Harm Reduction Journal, vol. 2, pp. 23, 2005.

[10] A. M. Bayoumi et al., "The Cost-Effectiveness of Vancouver's Supervised Injection Facility," CMAJ, vol. 179, no. 11, 2008.

[11] P. Vickerman et al., "The cost-effectiveness of expanding ham reduction activities for injecting drug users in Odessa, Ukraine," Sexually Transmitted Diseases, vol. 33, no. 10, pp. 89-102, 2006

[12] S. E. Habib et al., "Hepatitis C Prevalence And Risk Behavior Of Injecting Drug Users In Sydney: A Continuing Concern," South East Asian Journal Twp Med Public Health, vol. 32, no. 4, pp. 1-12, 2001.

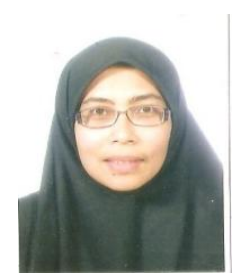

Sharifah Fadzlon Abdul Hamid was born in Singapore on 30th October 1962. She obtained her professional degree in Chartered Institute of Management Accountant (UK) in 1987. Ten years later she obtained her Master of Accounting from the Curtin University of Technology,Perth, Australia. She is a senior lecturer at the Faculty of Accountancy, Universiti Teknologi MARA (UiTM) teaching Advanced Financial Management and Strategic Finance for the Association of Chartered Certified Accountants (ACCA) and Chartered Institute of Management Accountants (CIMA) programmes at the Department of Professional Studies in UiTM. Her other teaching experience includes teaching Management Accounting, Cost Accounting and Finance for the undergraduates and the Malaysian Institute of Chartered Secretary and Administration (MAICSA) students. She was involved in various activities relating to teaching and learning while she was the Head of Management Accounting and Finance Discipline and the Head of the Quality Unit at the Faculty. Currently she is the CIMA advocates for the university and the Associate Editor for the Asia Pacific Management Accounting Journal (APMAJ).Her involvement with other Professional bodies include being the Examiner for the MAICSA and the Editor for the examination papers for the Malaysian Institute of Accountants' Qualifying Exam (MIAQE). Her research area include management accounting system, integrated strategic governance, supply chain management that have won several awards both at national and international level. She co-authors the books Corporate Finance, Malaysia ,Pearson, 2009 and Financial Markets, Malaysia, Mc Graw Hill,2011 that are currently used by the UiTM students as well as students from other universities. Her other publications include The Relevance of Management Accounting in Hiv-Aids Harm Reduction Programme(2012),MIA E-Book and Managerial Performance in Local Government Within An Islamic Cultural Setting (2007), Journal of Applied Management Accounting Research(JAMAR)

Associate Professor Sharifah Fadzlon Abdul Hamid has won silver award and consolation prize in the MIA Articles of Merit Award on Practice Accountants in Business(PAIB) for the year 2008 and 2011 consecutively. She has also won three gold, two silver awards and a bronze for the research sponsored by the Government of Malaysia entitled Integrated Strategic Governance Dashboard (ISG) at the national and international level.

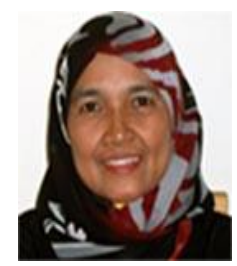

Normah Omar was born on 6 August 1955 in Selangor, Malaysia. She obtained her Diploma in Accountancy in 1977 from the Institute Teknologi MARA (ITM), Malaysia and proceed to do her BBA (Accounting) at the University of Iowa, USA in 1980
She obtained her MBA (Accounting) from Southern Illinois University, USA in 1982 and was awarded $\mathrm{PhD}$ (Accounting) from the Manchester Metropolitan University, UK in 1993.

She is a Professor in Management Accounting and Corporate Governance and is the Director of Accounting Research Institute (ARI) at the Universiti Technology MARA, which is one of the Malaysia's six centres of excellence recognised and funded by the Ministry of Higher Education Malaysia.Her research interest include Management Accounting, Forensic Accounting and Financial Criminology. As a proponent of applied research, Professor Normah has completed a lot of collaborative works with government agencies, professional bodies, regulators, non-government organizations and corporate sector. To mention a few, she has successfully completed research projects such Developing Fraud Risk Indicators in the Audit of Financial Statements, Bank Frauds through the use of cheques and credit cards, Anti-money Laundering and Anti Terrorism Financing in Financial Institutions, Management accounting practices Asia, Japanese Management Accounting in Automobile Industry, Corporate Governance Reporting and the National Award for Management Accounting (NAfMA). She has numerous publications and has presented in many conferences all over the world. Her publications include Moderating Effect of E-Commerce Experience on Usage Performance Relationship in Malaysia Service Industry, Journal of Systems and Information Technology. (SCOPUS) - 2011, Fraud Prevention Mechanisms of Malaysian Government-Linked Companies: An Assessment of Existence and Effectiveness, Journal of Management Accounting and Auditing (USA) ISSN 1548 6583, Fraud Diamond Risk Indicator : An Assessment of Its Importance Usage. 2010 International Conference on Scientific and Social Research (CSSR 2010), Seri Pacific Hotel, Kuala Lumpur, SCOPUS, IEEE Explore

Professor Dr Normah Omar has won 13 gold, 9 silver and 3 bronze awards for her numerous research and innovations.

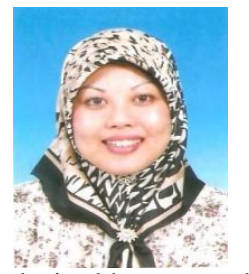

Suzana Sulaiman was born on 11 October 1965 in Johor, Malaysia. She obtained her Diploma in Accountancy from Institut Teknologi MARA in 1986 before proceeding to acquire the Professional degree from Chartered Institute of Management Accountant (CIMA) in the United Kingdom in 1991. In 1997 she was awarded Master of Accounting (distinction) from Curtin University of Technology, Australia and obtained her postgraduate Degree of Doctor of Philosophy (PhD) from the University of Edinburgh, Scotland in 2003.

Suzana Sulaiman (ACMA, CGMA \& CA) is a Professor of Management Accounting at Universiti Teknologi MARA (UiTM) Faculty of Accountancy, Malaysia. Her research interests and publications are in the areas of evolution of management accounting, enterprise governance and value management She is currently the Assistant Vice Chancellor (iLQAM), CIMA (UK) Research Board, Deputy Chairman, CIMA (UK) Malaysia Country Branch Committee, Head of Asian Management Accounting Research Centre (AMARC) and Managing Editor for Asia-Pacific Management Accounting (APMAJ), UiTM. Her past appointment to include as the CIMA Malaysian Treasurer and Divisional EXCO Member and Chairman for Assessment Committee, Malaysian National Award for Management Accounting (NAfMA) Best Practices. Her interests in management accounting have proven by the list of her publication, research books and proceedings. Several patented and trademark products were produced from these research. These products have won several awards at the national and international invention, innovation and design competitions. She was also invited to be speaker at several national and international interviews and conferences. She has published numerous papers which include The Influence of Culture on the Relationship Between Level of Participation Budgeting and Firm Performance in the Context of Libya,2011 Asian journal of Business management Studies 2 (2), 84 - 93, The Role of Management Accounting in the Successful Implementation of Strategy and Its Impact on Leverage and Performance,2009 (APMAJ), Vol 4, Issue 2 , Value Engineering Value Management Innovation in Automotive and Construction Companies: A Malaysian Multiple Case Scenario,2007, Journal of Accounting and Management Information Systems (JAMIS), 20, 78 - 97.

Professor Dr Suzana Sulaiman has won many awards which include 5 gold, 3 silver and 3 silver medals for her research at the national and international level. 